Academic City University College - Accra Ghana

Society for Multidisciplinary \& Advanced Research Techniques (SMART) Africa

Tony Blair Institute for Global Change

FAIR Forward - Artificial Intelligence for All - Deutsche Gesellschaft für Internationale Zusammenarbeit (GIZ) GmbH

Accra Bespoke Multidisciplinary Innovations Conference (ABMIC)

\& The Africa Al Stakeholders' Summit

$14^{\text {th }}$ December, 2021

\title{
Digital Environment in Academic Libraries: Leveraging on Advanced Information Communication Technologies for Better Service Delivery
}

\author{
Ngoaketsi, Joseph \\ Department of Information Science \\ University of South Africa, Pretoria, South Africa \\ E-mail: ngoakmj@unisa.ac.za \\ Salawu, Yetunde Khadija \\ Department of Library and Information Science, \\ Federal Polytechnic, Offa, \\ Kwara State, Nigeria \\ E-mail: kubsimail@yahoo.com \\ Tella, Adeyinka \\ Department of Library and Information Science, \\ University of Ilorin, Nigeria, Ilorin, Nigeria \\ Department of Information Science, University of South Africa, Pretoria, South Africa \\ E-mail: tella.a@unilorin.edu.ng
}

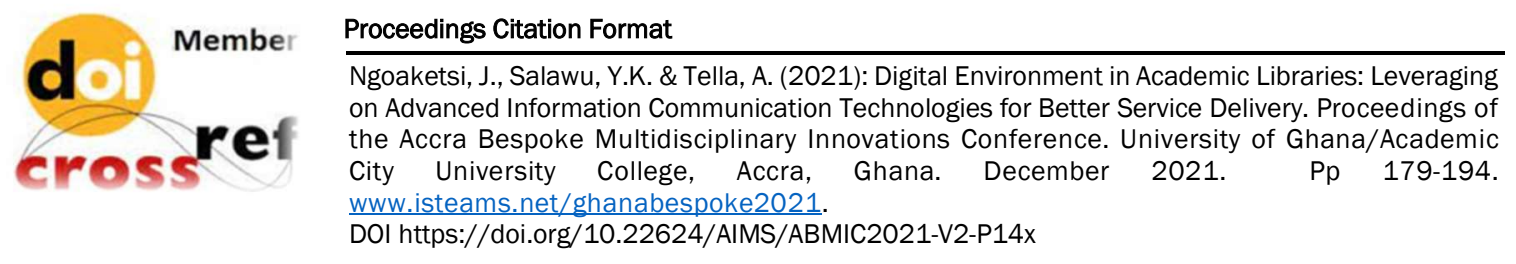




\title{
Digital Environment in Academic Libraries: Leveraging on Advanced Information Communication Technologies for Better Service Delivery
}

\author{
Ngoaketsi, J., Salawu, Y.K. \& Tella, A.
}

\begin{abstract}
The advancement in technologies coupled with the Fourth Industrial Revolution (4IR) and its associated technologies such as artificial intelligence, Al, robotic technology, virtual/augmented reality, big data, blockchain, cloud computing, and the likes have entered into the academic and other types of libraries have all brought changes into the digital environment of academic libraries. In light of this, this chapter examined the current digital environment of academic libraries. The chapter discusses the concept of the digital environment and academic libraries, describes digital components in academic libraries (old versus new), describes the impact of the digital environment on academic libraries, identify the new knowledge and skills required for academic libraries users' and librarians' functionality in the digital environment of academic libraries, and identifies changing formats ofthe environment of information material; the technological issue; the changing role of librarians; a collection of virtual information, archiving or preserving the virtual information; accessing of virtual information; special skills needed for librarians in building a virtual library; the cost factor of information technology; and the likelihood of job loss by the librarians as current challenges associated with the digital environment of academic libraries. The chapter recommends based on the findings that Academic librarians and studentsshould work to develop in-demand skills and continuously learn to use tools that reveal their capabilities and expertise to function in the digital environment of academic libraries and to provide efficient and effective information service. The academic librarians should anticipate and integrate new technologies to redesign access and delivery mechanisms to maximise utilisation of information and to minimise the costs of supporting such services.
\end{abstract}

Keywords: Academic libraries, Digital environment, Digital literacy, Digital skills, Advanced technologies, Fourth Industrial Revolution technologies.

\section{INTRODUCTION}

The advancement in information communication technology has resulted to change in the environment of libraries particularly the academic libraries which most often are the biggest. In light of this, the nature of academic libraries and the roles they play in our campuses are changing in the current digital environment. Libraries generally are now moving towards an information commons model of service and becoming campus community centers. The current scenario enables the academic libraries to now invite students and faculty for socialisation, learning, research, scholarship, and instruction. With the advancement in technology, academic libraries now increasingly provide information and services to users at the right time, to meet the right information needs.

There is no doubt thatthe digital environment now permeates every aspect of our lives including homes, schools, workplaces, public spaces such as transport stations, libraries, cafes, cities), and government. Emphatically, it is difficult to get away from the digital environment. 
The Post Modern Bible Blogs (2020) postulate that "even those who continue to resist computer, faxes, email, personal digital assistants, let alone the internet and the World Wide Web, can hardly avoid taking advantage of the embedded microchips and invisible processors that make phones easier to use, cars safer to drive, appliances more reliable, utilities more predictable, toys and games more enjoyable and the trains run on time" With this development, and the transformation brought by the Fourth Industrial Revolution 4IR and its associated technologies which have entered into the academic and other libraries such as artificial intelligence, Al, robotic technology, virtual/augmented reality, big data, blockchain, cloud computing, and the likes have all brought changes into the digital environment of academic libraries.

However, from the extant literature, it seems as if this change has not been adequately explored to reveal the current digital environment in academic libraries particularly in the context of Nigerian academic libraries. Doing this is considered very important because it will reveal and expose the current changes that are taking place, what the academic libraries need to do to cope with the changes for them to move to the next level and compete favourably with their counterparts in the developed nations of the world. It is upon this premise that this chapter examined the digital environment of academic libraries by looking at what digital environment and academic libraries entail, the digital components in academic libraries (old versus new), the impact of the digital environment of academic libraries, the new knowledge and skills required for functionality in the digital environment of academic libraries both by the users and the librarians, the current challenges associated with the digital environment of academic libraries, and then profers recommendation/way forward based on the findings from the discussions on each of the focus of the chapter.

\section{LITERATURE REVIEW}

\section{Digital Environment}

As postulated by IGI Global (2020), a digital environment is typically an integrated communication environment where digital devices communicate and manage the content and activities within it. IGI Global posited that this concept is based on digital electronic systems that are integrated and implemented particularly in libraries for a global community. The same author thought that the digital environment is a context or a place that is enabled by technology and digital devices, often transmitted over the internet or other digital means such as a mobile phone network. The author added that records and evidence of an individual's interaction with the digital environment constitute their digital footprint.

Furthermore, the digital environment is explained to mean an environment as the cultural and communicative environment that shapes media messages and communication activity; an environment with the dominant communication form of the twenty-first century by which we understand and operate in the world at present, it is a social setting produced through technology. Considering these definitions, the digital environment is hereby summarised in this chapter as the conglomeration of all new events of technology integrations, facts, and realities into a tangible experience of a changed way of information dissemination in academic libraries. A cultural shift that has happened where a technological leap forward has matched with or been contemporaneous with sympathetic philosophical and pedagogical advances. 


\section{Academic Libraries}

An academic library is a library that is attached to academic institutions above the secondary level, serving the teaching and research needs of students and staff. These libraries serve two complementary purposes: to support the school's curriculum and to support the research of the university faculty and students. The support of teaching requires material for class readings and student papers. In the past, the material for class readings, intended to supplement lectures as prescribed by the instructor, has been called reserves. The information age academic library is a laboratory of learning where abundant information resources in all formats and their accompanying infrastructure are available for exploration and skills development. Academic libraries must decide what focus they take in collecting materials since no single library can supply everything. When there are particular areas of specialisation in academic libraries these are often referred to as niche collections. These collections are often the basis of a special collection department and may include original papers, artwork, and artifacts written or created by a single author or about a specific subject.

\section{DIGITAL COMPONENTS IN THE DIGITAL ENVIRONMENT OF ACADEMIC LIBRARIES (OLD VERSUS NEW)}

The digital environment of academic libraries comprises digital components that are either old or new. The old ones are those in existence before and during the internet revolution; while, the new ones are the ones ushered in by the fourth industrial revolution. These components are discussed in detail as follows.

\section{Old Components}

Automation:Library automation is the conversion of a library's procedures from manual to computerised, such as from a card catalogue to an OPAC, or from manual circulation cards to an integrated library system. Automation is a process of using machinery for easily working and saving human power and time.

Online Public Access Catalogue: An online public access catalogue, also known as OPAC, is an online database of all the resources and materials held by a particular library. It is a card catalogue, of sorts, that is accessed via a computer or other electronic device. Online public access catalogues could potentially replace the old-fashioned card catalogue as a means of helping library visitors locate the resources they seek. Users can search the database electronically, which can provide them with a quicker and more thorough means of locating necessary information, resources, books, literature, or other materials. One of the unique aspects of an online public access catalogue is that it is user-friendly and accessible by all parties. That means that anybody, regardless of their age, status, or even their level of knowledge about computers, can use the system. If help is needed in a search, the system itself is designed to offer that assistance by use of various prompts, suggestions, help topics, FAQs, and even error messages when needed. Search results are displayed in a format that is easy to read and understand.

CD-ROM: "Compact Disc Read-Only Memory." A CD-ROM is a CD that can be read by a computer with an optical drive. The "ROM" part of the term means the data on the disc is "read-only," or cannot be altered or erased. A CD-ROM Drive or optical drive is the device used to read them. CD-ROM drives have speeds ranging from $1 x$ to $72 x$, meaning it reads the CD roughly 72 times faster than the $1 x$ version. As can be imagined, these drives are capable of playing audio CDs and reading data CDs, including CD-R and CD-RW discs. 
Flash Drives: A flash drive is a small, ultra-portable storage device which, unlike an optical drive or a traditional hard drive, has no moving parts. Flash drives connect to computers and other devices via a built-in USB Type-A or USB-C plug, making a flash drive a kind of combination USB device and cable. Flash drives are often referred to as pen drives, thumb drives, or jump drives. The terms USB drive and solid-state drive (SSD) are also sometimes used but most of the time those refer to larger, not-so-mobile USB-based storage devices like external hard drives.

Hard Drives: A hard disk drive (sometimes abbreviated as a hard drive, HD, or HDD) is a nonvolatile data storage device. It is usually installed internally in a computer, attached directly to the disk controller of the computer's motherboard. It contains one or more platters, housed inside of an air-sealed casing. Data is written to the platters using a magnetic head, which moves rapidly over them as they spin. Internal hard disks reside in a drive bay, connected to the motherboard using an ATA, SCSI, or SATA cable. They are powered by a connection to the computer's PSU (power supply unit). Examples of data stored on a computer's hard drive include the operating system, installed software, and the user's files.

\section{New Components}

As Onuoha and Obialor (2015) rightly observed, the invention of Information and Communication Technology now enables libraries to use various types of technologies to aid the services they render. Daily, new technological advances affect the way information is processed and handled in academic libraries and information centres. As pointed out by Satell (2018), our world has been thoroughly changed by digital technology. As mentioned earlier, there are the latest technologies or technological tools or components that are building the digital environment of academic libraries (Corfe, 2018; Tella, 2020). These technologies are described in turns as follows.

Artificial Intelligence, Al: The University of Queensland Australia (2020), defined Al as a machine behaving intelligently by problem-solving or completing tasks. It is a very broad subject that involves computer science, cognitive science, mathematics, philosophy, neuroscience, linguistics, and other disciplines. Irrespective of the way Al is defined, the definitions usually talk about imitating human behaviour which is already a much brawny definition. Hitherto, the Al society has been striving to emulate intelligent behaviour with computer programmes. This is not an easy operation since a computer programme must be able to do various things for it to be called intelligent. Aside from looking at the general definition of Al, experts canalso restrict themselves to the definition of artificial intelligence systems. However, irrespective of the definitions available, they can be classified into four categories (TechTarget, 2020): systems that think like humans, a system that acts like humans, systems that think rationally, and systems that act rationally. According to Hintze (2016), Al can be categorised into four. These are reactive machines, limited memory, the theory of mind, and self-awareness.Just like other areas of our lives, Al has also been applied in libraries in the form of chatbots that can handle directional questions on a library website, alert librarians and borrowers when a book is due, and point a user to relevant library resources or answer simple information requests.

Big Data: Gartner Glossary (2020), looked at big data as a high volume, velocity, and variety of information assets that demand cost-effective, innovative forms of information processing for enhanced insight and decision making. So also, big data is an extensive dataset, primarily in the characteristics of volume, velocity, and/or variety, which require a scalable architecture for efficient storage, manipulation, and analysis (University of Wisconsin, 2020).Big data can be categorized into three (Rai, 2020). The three categories are structured, unstructured, and semi- 
structured. Academic libraries make use of big data to implement knowledge as well as improve their services (Kamupunga\&Chunting, 2019). As highlighted by Coelho (2011), academic libraries face internal and external pressure to changes, and they have to respond positively to user requirements and content delivery. In other words, academic libraries can use big data to make better decisions and create better services, use the patron database combined with GIS mapping to find out more about their patrons and where the non-patrons live; to determine materials that users want to check out; tracking other library-related analytics; and also to help improve student retention (and getting more students into the library).

Blockchain: Tella (2020) refers to the blockchain as a simple but ingenious way of transporting information from one place to the other in a fully automated and safer manner. The author emphasised that one party to a transaction initiates the process by creating a block. This block is verified by thousands, perhaps millions of computers distributed around the net. The verified block is added to a chain, which is stored across the net, creating not just a unique record, but a unique record with a unique history. In the simplest term, it a time-stamped series of immutable records of data that is managed by a cluster of computers not owned by any single entity (Tella, 2020). Academic can use blockchain in archiving special collections, including records management, where provenance and authenticity are essential for authoritative tracking and where providing broader access to that provenance and authenticity is expected. Existing blockchain platforms in academic libraries could support provenance metadata for archival assets and offer a superior solution to the current fragile, labor-intensive record-keeping workflows.

Could Computing: Cloud computing is a combination of technology with trends that makes infrastructures and applications more dynamic, flexible, and usable (Suman and Singh (2016). Applications such as e-mail, online banking, web conferencing, customer relationship management (CRM) all are tracked in the cloud. It is a style of computing in which massively scalable and elastic IT-enabled capabilities are delivered as a service to external customers using Internet technologies. Similarly, (Investopedia, 2020) explained that cloud computing is the delivery of different services through the internet. These resources include tools and applications such as data storage, servers, databases, networking, and software. In other words, cloud computing is the delivery of computing services including servers, storage, databases, networking, software, analytics, and intelligence over the internet ("the cloud") to offer faster innovation, flexible resources, and economies of scale. The academic library community now applies the concept of cloud computing to amplify the power of cooperation and to build a significant, unified presence on the Web. This approach helps academic libraries to save time and money, increase cooperation among libraries, make libraries greener while simplifying workflows (Goldner, 2011).

Robotic Technology: A Robot is a machine capable of carrying out a complex series of actions automatically, especially one programmable by a computer (Abraham, 2019). Robots are a mechanical device that performs automation tasks, either according to direct human supervision or a pre-defined program or a set of general guidelines, using artificial intelligence techniques (Nowrin, 2020). Robotic technology has revolutionised information service delivery in libraries in different ways. Apart from automated information storage and retrieval, libraries have deployed robots for both internal operations and public services. For instance, there are autonomous shelf reading robots, as well as telepresence, Chatbots, and humanoid robots for reference services and maintenance of circulation records in the library. 
These robots are assigned repetitive task in the library, thus, ensuring that these services are rendered efficiently and effectively (Tella, 2020). In academic libraries, robots are used to teach coding and computer-programming skills, take verbal book requests, work out where the hard copy is and lead students to the relevant bookshelf. Also, the temperature and the humiditycontrolled store is operated by robot cranes and can retrieve newspapers from any time and date (Nowrin, 2020).

Internet of Things, loT: According to Mcelland (2020), loT is a system of interrelated computing devices, mechanical and digital machines, objects, animals, or people that are provided with unique identifiers and the ability to transfer data over a network without requiring human-tohuman or human-to-computer interaction." loT refers to the billions of physical devices around the world that are now connected to the internet, all collecting and sharing data. IoT is about extending the power of the internet beyond computers and smartphones to a whole range of other things, processes, and environments.

In academic libraries, loT is now being used to inform users about overdue books and how much fine they owe to the library, to enable them to return the overdue books and pay the fine online without needing to stand in a queue at the library circulation desk (Roullard, 2015). IoT also helps in inventory management (stock verification) as it makes it easy to locate misplaced books in the library. Users can also track Wi-Fi devices to show traffic patterns and identify popular shelves to make better informed space-usage decisions (Abo-Seada, 2019).

It should be noted that the new technology components have brought several impacts into the digital environment of academic libraries. These impacts are discussed in the next section.

\section{IMPACT OF DIGITAL ENVIRONMENT ON ACADEMIC LIBRARIES}

As mentioned earlier the advancement in technologies has changed the landscape of libraries especially academic libraries and this has impacted academic libraries considerably. These impacts are highlighted and discussed as follows.

Equitable access. The International Federation of Library Associations' IFLA (2012) Manifesto for Libraries Serving Persons with a Print Disability indicates that there are over 161 million blind and partially sighted people worldwide. This is in addition to persons with other print disabilities who cannot effectively read print because of a physical, perceptual, developmental, cognitive, or learning disability. Together, this makes up a very large number of people who cannot read a conventional book, magazine, or website. As maintained by Patrickson-Stewart and Nadine Newman (2017), less than 5 percent of all published materials and reportedly less than 20 percent of websites accessible to this group. IFLA is therefore recommending that all library and information providers provide services, collections, equipment, and facilities to assist printdisabled persons to access and use resources that meet their particular information needs.

Libraries around the world especially academic libraries are supporting visually impaired students by ensuring equitable access to resources. This is made possible due to digitisation of the library environment. Academic libraries are now committed to providing an inclusive library environment where all readers have complete and equitable access to the entire library service. Access to library buildings is now disabled friendly, special borrowing privileges are extended to registered students and staff with disabilities and Educational Support workers assist persons who have challenges with searching, retrieving, borrowing, etc. 
Students who cannot use regular print materials and need resources in an alternative format request resources in audio, large print or braille). In most academic libraries nowadays, there are also "Assistive Technology Information Centers" with computers loaded with assistive software for use by print-challenged students.

Extended opening hours: Another important impact of the digital environment of academic libraries is the extended opening which allows users more time to study and conduct research in an environment that is conducive to learning, and which has technological devices that are not necessarily available to them elsewhere. To facilitate customers, some academic libraries now offer extended opening hours as a service to users; some as much as 24 hours per day particularly during the end-of-semester examinations period. A check on some academic library websites in Nigeria for example,the University of Ibadan, University of Lagos, University of Ilorin, and others reveals that they offer $24 / 7$ opening during exam periods. This is also the case with libraries in some foreign universities e.g. Trinity College Library in Dublin, Maastricht University Library in The Netherlands, and other academic libraries across continents that offer an extended opening for the benefit of users particularly during the examination period (Patrickson-Stewart \& Nadine Newman, 2017).

This trend is in line with a study done on the extended opening hours of three public university libraries in Nigeria - LAUTECH University Library, University of Ilorin Library, and Kenneth Dike Library at the University of Ibadan (Womboh\& Abba, 2008). The researchers found that more than 80 percent of the student population agreed that the libraries' extended opening hours significantly improved their academic performance (Womboh\& Abba, 2008; Ajala, Arinola, Adigun, \&Ogunmodede, 2014). The authors believe that there is an increase in the demand for information and the university libraries cannot afford to close its doors on users' expectations, particularly during examination periods (Womboh\& Abba, 2008).

Digital publishing platforms: It has been established that faculty, university presses, libraries, and individual researchers have been showing interest in providing open and easy access to their scholarly works and scientific research and that providing such electronic access through the Web could be the simplest, most economical and powerful means of achieving this (Cyzyk\& Choudhury, 2008). Some academic libraries are therefore utilising digital publishing platforms to provide access, disseminate, and preserve these resources. A very good example is the project at Johns Hopkins University (JHU) libraries presented by Cyzyk and Choudhury (2008).

Consortia and resource sharing: Consortia and resource sharing have been used by libraries over the centuries to respond to budgetary challenges. Libraries continue to use these strategies to equip themselves with the technology they need to attract and keep their patrons (Igwe, 2010' Tella \&Sidiq, 2018). Reitz (2014) defines consortium as an "association of independent libraries and/or library systems established by formal agreement, usually for resource sharing". The author defined resource sharing as "the activities that result from an agreement, formal or informal, among a group of libraries. Resources shared are not limited to funding, but also include sharing through inter-library loans and expertise (Owolabi et al., 2011; Tella, Qurdri, Bamidele, \&Ajiboye, 2020). Through membership in consortia, libraries around the world have been able to share the cost of implementing information technology. 


\section{KNOWLEDGE AND SKILLS FOR FUNCTIONALITY IN DIGITAL ENVIRONMENT OF ACADEMIC LIBRARIES}

Technology is transforming the traditional methods of teaching and learning in the classrooms of the 21st Century. The goal is to enable students to become active, self-sufficient, and lifelong learners rather than passive recipients of the information. The same transformation is also taking place in academic libraries as earlier emphasised. Therefore, this new approach to education and libraries takes the students beyond the traditional textbook and requires students to develop a combination of skills in computer technology, critical thinking, and information-seeking strategies. Society has long viewed and acknowledged librarians as information experts. The modern librarians represent a professional group that long ago learned to bridge the gap between the traditional methods and the modern technological techniques used in the organisation, management, and retrieval of information. The transformed landscape in the digital environment of academic libraries requires a new generation of librarians to effectively and efficiently mediate it.

On this note, Orme (2008, p. 627-628) categorised knowledge and skills required to explore this transformed environment into discipline-specific knowledge (that is, the knowledge that relates specifically to the LIS profession), generic skills (general skills which apply to all disciplines) and personal competencies (attitudes, values, and personal traits). Choi and Rasmussen (2009, p. 465), through content analysis of job advertisements in the United States of America (USA), found that key disciplinary knowledge required for this digitally oriented environment included understanding metadata and knowledge and experience in digital content creation and management. Generic skills such as effective communication and interpersonal skills, critical thinking, problem-solving, and teamwork were found by Nonthacumjane (2011, p. 283) to be required by information professionals in a digital library environment. Howard's (2009) Australian master's study (cited in Nonthacumjane, 2011, p. 283) highlighted personal competencies such as flexibility, adaptability, and reflective thinking as being required for working in a digital library environment.

Disciplinary Knowledge: Partridge and Hallam (2004) use the "double helix image of human DNA" to argue that both disciplinary knowledge and generic capabilities "make up the genome of the successful information professional in the information age". Similarly, scholars have argued that the new digitally oriented academic library is a renewed conceptualisation of traditional LIS resources and services, now undergirded and driven by new technologies (Choi \& Rasmussen, 2009, p. 465; Gerolimos\&Konsta, 2008, p. 697). Hence in a digital academic library environment core knowledge and skills of traditional librarianship are important but need to be augmented by new technological knowledge (Choi \& Rasmussen, 2009, p. 465).

Digital library applications are closely intertwinedwith Web technology (Choi \& Rasmussen, 2009, p. 463). Consequently, as modern academic libraries move into the creation of digital content and its organisation and preservation through metadata creation and management to make their special collections more accessible via the Web. Therefore, the need for knowledge of the following technologies on the part of the users and librarians becomes crucial: digital library architecture and software, technical and quality standards, HTML coding, general computer skills and computer literacy, database development and management, Web mark-up languages such as SGML and XML, and Web development and design (Choi \& Rasmussen, 2006; Choi \& Rasmussen, 2009, p. 463). 
In a similar vein, Ocholla and Shongwe $(2013$, p. 39, 42) in their content analysis of job advertisements in South Africa over four years (2009-2012) found IT skills to be very sought after in libraries as "more information services", particularly in academic and research environments, become "IT or e-access and e-service dependent".

Extant literature on innovative and advanced technology has identified several skills necessary for students and librarians in academic libraries to be able to annex, access, and explore the digital environment in academic libraries. The technology discussed above, cannot be operated by students and academic librarians if they don't possess the required skills. The assumption is that the future of the digital environment in academic libraries is accelerating in various dimensions. Librarians and students will need the capacity to analyse problems, generate new ideas, navigate sources of knowledge, pivot and develop a new strategy to solve practical problems, and support patrons in satisfying their information need. However, the shift in focus from knowledge to skills is expressed in discussions and advocacy around the new advanced technology skills. These are the skills considered necessary to thrive and survive in a wave of constant change and disruption. The skill varies, of course, but there is a remarkable constant degree of overlapping. For example, see Table 1 for the required skills by various professionals including librarians.

Table 1: Required Skills by Various Professionals in the 4IR

\begin{tabular}{|r|l|l|l|}
\hline NO. & $\begin{array}{l}\text { World Economic Forum } \\
(\text { Gray, 2016) }\end{array}$ & $\begin{array}{l}\text { Education Design Lab } \\
(2018)\end{array}$ & $\begin{array}{l}\text { Institute for the Future } \\
(2011)\end{array}$ \\
\hline 1. & Complex problem solving & Initiative & Sense-making \\
\hline 2. & Critical thinking & Collaboration & Social intelligence \\
\hline 4. & Creativity & Creative problem solving & $\begin{array}{l}\text { Novel and adaptive } \\
\text { thinking }\end{array}$ \\
\hline 5. & Coordinating with others & Intercultural fluency & $\begin{array}{l}\text { Cross-cultural } \\
\text { competence }\end{array}$ \\
\hline 6. & $\begin{array}{l}\text { Judgement and decision } \\
\text { making }\end{array}$ & Empathy & Computational thinking \\
\hline 7. & Service orientation & Oral communication & Transdisciplinarity \\
\hline 8. & Negotiation & Resilience & $\begin{array}{l}\text { Design mindset } \\
\text { management load }\end{array}$ \\
\hline 9. & Cognitive flexibility & & Virtual collaboration \\
\hline 19. & &
\end{tabular}

Most of these skills are expressions of emotional intelligence which will be one of the defining characteristics of the fourth industrial revolution 4IR librarian. Emotional intelligence will become one of the top skills needed by all. As machines will take over technical operations, librarians will begin to place greater value on soft skills and tasks that cannot be performed by robots. The reality is that change would not wait for librarians to be proactive in up-skilling; they just need to start training now to benefit from the fourth industrial revolution and advanced technology era. 


\section{CURRENT CHALLENGES POSED BY THE DIGITAL ENVIRONMENT OF ACADEMIC LIBRARIES}

New technologies are changing the services that libraries provide; for example, online reference and instruction, desktop document delivery, self-checkout, and user-initiated library loan and direct borrowing. It is a fact that in this part of the world, training and education for librarians are grossly inadequate as evident in the limited number of skilled librarians available to actualise the transformation from purely traditional to purely electronic or at least hybrid library services. The present digital environment leads to sophisticated and challenging tasks for academic libraries. This section details the challenges faced by the users in the digital environment of academic libraries.

$>$ Changing formats environment of the information material.

$>$ Technological challenges.

$>$ Changing role of librarians.

$>$ Challenges in the collection of virtual information, archiving or preserving the Virtual Information.

$>$ Challenges in accessing virtual information.

$>$ Special skills are needed for librarians to face the challenges in building a virtual library.

The cost factor of information technology has positively affected user services in many ways. However, the issue of cost has impeded the efforts of academic libraries in some countries, as it relates to IT implementation. Costs associated with information technology implementation include the acquisition of hardware and software, consultancy, maintenance, internet services, and training (Womboh and Abba, 2008). Saarti (2003) acknowledged that acquiring and maintaining library automation and digital environment of academic libraries require large capital investments and explains that costs associated with software acquisition and system maintenance are approximately half the initial cost of implementation. With the global economic downturn affecting libraries in both developed and developing countries, the likelihood of academic libraries in the English-speaking West Africancountries acquiring expensive computerised systems without financial assistance is discouraging. West African sub-region, like other parts of the world, is plagued with adverse economic conditions, dwindling budgets, and a rapidly evolving information technology landscape.

Parallel to the development of digitisation and curation of unique collections, the digital environment of academic libraries is also being challenged by an emerging trend of research data management and curation (Wise, Henninger, \& Kennan, 2011, p. 279). The emergence of eScience and eResearch is accompanied by the generation of vast amounts of research data in need of collection, preservation, management, and provision for future access to enable reusing, repurposing, re-combining, etc (Patrickson-Stewart and Nadine Newman (2017). According to Luce (2008) metadata is an essential component of research data and research or academic libraries, because of their traditional knowledge base, are well-positioned to "lead the development of standardised, ontologically rich automated metadata" for research data sets. Here again, disciplinary knowledge, that is, the creation and management of metadata which are established tasks in the LIS profession, allows academic libraries to take responsibility for the curation and preservation of data for its re-use when needed (Luce, 2008).

Likelihood of job loss: There is the tendency that the improvement in the digital environment of academic libraries consequent on the integration of advanced technologies could result in job loss for the librarians. The World Economic Forum (2018) reported that by 2030, robots will 
replace 800 million workers across the world. This is a strong signal and message to the librarians whose skills are currently nothing to write home about.SCONUL (2017) also reported that library staff often shows resistance to change and even a sort of defensiveness in their approach to technological change. Such librarians may have to contend their jobs with robots. Considering these statistics and forecasts, it should be noted that many librarians and other information professionals will likely lose their job just as researches and statistics have shown so far.

\section{CONCLUSION}

The chapter has discussed the concept of the digital environment of academic libraries, described digital components in academic libraries (old versus new), described the impact of the digital environment on academic libraries, identify the new knowledge and skills required for users' and librarians' functionality in the digital environment of academic libraries, and has identified changing formats environment of information material; technological issues; changing role of librarians; a collection of virtual information, archiving or preserving the virtual information; accessing virtual information; special skills needed for librarians to face the challenges in building a virtual library; the cost factor of information technology; and the likelihood of job loss by the librarians as the current challenges associated with the digital environment in academic libraries.

\section{RECOMMENDATIONS}

1. Based on the discussion and the findings evident from this chapter, the following are recommended.

2. Academic librarians and students should also work to develop in-demand skills and continuously learn to use tools that reveal their capabilities and expertise to function in the digital environment of academic libraries and to provide efficient and effective information service.

3. The Academic Librarians should anticipate and integrate new technologies to redesign access and delivery mechanisms to maximise utilisation of information and to minimise the costs of supporting such services.

4. The need for training is considered very important. Being technology literate is the first step towards building environments where humans and robots for instance can work together. As Al, robotic and other advanced technologies are now entering libraries, academic librarians should forget about conservatism because the reality is that these technologies may replace the slothful and conservative librarians/information professionals. Therefore, training and re-training, and up-skilling should be taking seriously (Tella, 2020).

5. Importantly, the academic librarian must be a leader to shape the use of advanced technologies in the digital environment of academic libraries positively because "an important part of leadership is not just responding to changes, but getting in front of those changes as much as we can' (Bourg, 2017, para. 14).

6. Kane (2019) indicated that so far, advanced technologies like Al has only made a small impact on academic libraries with some niche applications that are now only beginning to take the public stage. Therefore, academic librarians need to grasp this crucial topic and develop an informed opinion, so they can make the best use of these technologies and influence their evolution. 


\section{REFERENCES}

1. Abo-Seada, A.A. (2019). The Impact of the Internet of Things on Libraries and Users. Computers in Libraries, 30(1), http://www.infotoday.com/cilmag/jan19/Abo-Seada-The- Impact-of-the-Internet-of-Things-on-Libraries-and-Users.shtml

2. Abraham, S. (2019). Robots in libraries: Technology trends that aren't that out-there anymore!.https://lucidea.com/blog/robots-in-libraries/

3. Ajala, I.O., Arinola, A.A., Adigun, G.O. and Ogunmodede, T.A. (2014). Extended hours in academic libraries: the experiences of three public universities in South Western Nigeria", American International Journal of Contemporary Research, 4(4), 165 172.

4. Bourg, C. (2017). What happens to libraries and librarians when machines can read all the books? Retrieved from https://chrisbourg.wordpress.com/2017/03/16/whathappens- to-libraries-andlibrarians-when-machines-can-read-all-the-books/

5. Coelho, H. (2011). Web 2.0 in academic libraries in Portuguese public universities: A longitudinal study.Libri: International Journal of Libraries \& Information Services, 61, 249-257.

6. Choi, Y., \& Rasmussen, E. (2006). What is needed to educate future digital librarians: A study of current practice and staffing patterns in academic and research libraries.D-Lib Magazine, 12(9) (Retrieved May 14, 2012, from http://www.dlib.org/dlib/september06/choi/09choi.html).

7. Choi, Y., \& Rasmussen, E. (2009). What qualifications and skills are important for digital librarian positions in academic libraries? A job advertisement analysis. The Journal of Academic Librarianship, 35(5), 457-467

8. Corfe, S. (2018). 4IR in the Workplace: Ensuring employers and employees benefit. The Social Market Foundation, 11 Tufton Street, London SW1P 3QB.

9. Cyzyk, M. and Choudhury, S. (2008). A survey and evaluation of open-source electronic publishing systems", JScholarship, available at: http://jhir.library.jhu.edu/handle/1774.2/32737.

10. Education Design Lab (2018). Education Design Lab Releases 21st Century Skills Badge Program. Retrieved from https://eddesignlab.org/news-events/education-design-labreleases-21st-century-skills-badge-program/

11. Gartner Glossary (2020). Big data. Retrieved https://www.gartner.com/en/informationtechnology/glossary/big-data\#: :text=B\%20Big\%20Data-

,Big\%20Data,decision\%20making\%2C\%20and\%20process\%20automation (accessed 7 July 2020).

12. Hintze, A. (2016). Understanding the four types of artificial intelligence. The Conversation, Retrieved: https://www.govtech.com/computing/Understanding-theFour-Types-of- Artificial-Intelligence.html

13. Howard, K (2009) (Digital library) education or (digital) library education? An Australian perspective (Master's thesis). Oslo University College; Tallinn University and the University of Parma

14. Gerolimos, M., \&Konsta, R. (2008). Librarians' skills and qualifications in a modern information environment. Library Management, 29(8/9), 691-699.

15. Goldner, M. (2011). Winds of change: Libraries and cloud computing. Retrieved from https://www.oclc.org/content/dam/oclc/events/2011/files/IFLA-winds-of-changepaper.pdf

16. IGI-Global (2020). What is digital environment? Retrieved from: https://www.igiglobal.com/dictionary/models-of-competences-for-the-real-and-digital-world/7610 
17. Igwe, K.N. (2010). Resource sharing in the ICT era: the case of Nigerian university libraries. Journal of Interlibrary Loan, Document Delivery \& Electronic Reserve, 20 (3), 173- 187.

18. International Federation of Library Associations (2012), IFLA Manifesto for Libraries Serving Persons with a Print Disability, IFLA, available at: www.ifla.org/publications/ifla- manifesto-for-librariesserving-persons-with-a-printdisability (accessed 11 July 2016).

19. Institute for the Future for the University of Phoenix Research Institute (2020). Future work skills 2020. Retrieved from https://www.iftf.org/uploads/media/SR1382A_UPRI_future_work_skills_sm.pdf

20. Investopedia (2020). Cloud computing. Retrieved from: www.investopedia.com/terms/ c/cloud-computing.asp/

21. Kamupunga, W. \&Chunting, Y. (2019). Application of Big Data in Libraries. International Journal of Computer Applications, 178 (16), 34-38.

22. Kane, D. (2019). Artificial Intelligence and Libraries - The 2019 Annual LIR Seminar. LibFocus.

23. Luce, R. E. (2008). A new value equation challenge: The emergence of eResearch and roles for research libraries. Retrieved January 22, 2013, from. http://www.clir.org/pubs/ reports/pub142/luce.html

24. Mcelland, C.(2020). What is loT? - A Simple Explanation of the Internet of Things. Retrieved from https://www.iotforall.com/what-is-iot-simple-explanation

25. Nonthacumjane, P. (2011). Key skills and competencies of a new generation of LIS professionals. IFLA Journal, 37(4), 280-288.

26. Norwin, S. (2020). Al, robot and library: A new dimension in LIS. https://shohanasite.wordpress.com/2016/12/04/ai-robot-and-library-a-newdimension- in- lis/

27. Ocholla, D., \&Shongwe, M. (2013). An analysis of the library and information science (LIS) job market in South Africa. South African Journal of Libraries and Information Science, 79(1), 35-43, http://dx.doi.org/10.7553/79-1-113.

28. Onuoha, Jude \&Obiano, Doris Chinyere. (2019). The Impact of Information Technology on Modern Librarianship: A Reflective Study. Information and Knowledge Management, 5(11), 52-58.

29. Orme, V. (2008). You will be ...: A study of job advertisements to determine employers' requirements for LIS professionals in the UK in 2007. Library Review, 57(8), 619-633.

30. Owolabi, K., Bamigboye, B.O., Agboola, I.O. and Lawal, W.O. (2011). Resource sharing in Nigerian University libraries: a survey. Journal of Interlibrary Loan, Document Delivery \& Electronic Reserve, 21(4), 207-216.

31. Patrickson-Stewart, S.G. \& Newman, N. (2017). User services in the digital environment Implications for academic libraries in the English-speaking Caribbean. Library Review, 66 (4/5), 213-234.

32. Partridge, H., \& Hallam, G. (2004). The double helix: A personal account of the discovery of the structure of [the information professional's] DNA. Paper presented at the ALIA 2004 Biennial Conference, Gold Coast, Australia, 21-24 September 2004 Retrieved January 25, 2013, from http://conferences.alia.org.au/alia2004/pdfs/partridge.h. paper.pdf.

33. Peltier-Davis, C. (2011). Overview of library services in the English-speaking Caribbean management, innovative services and resource sharing", World Library and Information

Congress: 77th International Federation of Library Associations General 
Conference and Assembly, San Juan, Puerto Rico, 13-18 August, available at: www.ifla.org/past- wlic/2011/81-davis-en.pdf

34. Post Modern Bible Blogs (2020). What do we mean by a digital environment? Retrieved from:

35. https://postmodernbible.blogs.com/files/what-does-codec-mean-by-a-digitalenvironment.pdf

36. Rai, A. (2020),'What is big data - characteristics, types, benefits and examples?,' Retrieved from https://www.upgrad.com/blog/what-is-big-data-typescharacteristics-benefits-

andexamples/\#: :text=It\%20refers\%20to\%20a\%20massive,data\%20sharing\%2C\%20 and\%20data\%20visualization.

37. Reitz, J.M. (2014). Online Dictionary for Library and Information Science, Libraries Unlimited, Westport, CT.

38. Roullard S, (2015). The Internet of things in the library. Available at: http://libserra.com/the- internet-of-things-in-the-library/ (Accessed on 27 May 2015)

39. Saarti, J. (2003). The acquisition and maintenance costs associated with library automation systems in Finnish public libraries. Program, 37(1), 25-30.

40. Satell, G. (2018). The industrial era ended, and so will the digital era. Retrieved from https://hbr.org/2018/07/the-industrial-era-ended-and-so-will-the-digital-era

41. SCONUL Report (2017). Mapping the Future of Academic Libraries: A Report for SCONUL. https://sconul.ac.uk/sites/default/files/documents/SCONUL\%20Report\%20Mapping $\% \quad$ 20the\%20Future\%20of\%20Academic\%20Libraries.pdf

42. Suman, A. Singh, P. (2016). Cloud computing in libraries: an overview. International Journal of Digital Library Services, 6(1), 121-127.

43. TechTarget (2020). What is artificial intelligence? Retrieved from https://searchenterpriseai.techtarget.com/definition/Al-Artificial-Intelligence

44. Tella, Adeyinka (2020). Repackaging LIS professionals and libraries for the fourth industrial revolution. Library Hi Tech News, 37 (8), 1 6.https://doi.org/10.1108/LHTN-02- 2020-0016.

45. Tella, Adeyinka (2020). Robots are coming to the libraries: are librariansready to accommodate them?Library Hi Tech News, 37(8), 1317.https://doi.org/10.1108/LHTN-02-2020-0016.

46. Tella, Adeyinka, Akande, F.T. \&Bamidele, S.S. (2019) ICT knowledge and skills required for recruitment of academic librarians in the digital age. Library Philosophy and Practice (e-journal)http://digitalcommons.unl.edu/libphilprac/1953

47. Tella, Adeyinka. \&Sidiq, A.O.(2018).Interlibrary loan and cooperation among selected academic libraries in Kwara state, Nigeria: an empirical analysis. Journal ofInterlibrary Loan, Document Delivery and Electronic Reserves, 26(2), 103- 120.Published by Taylor and Francis Rutledge. DOI: 10.1080/1072303X.2017.1386602.

48. Tella, Adeyinka, Quardri, F. Bamidele, S.S. \&Ajiboye, O.O. (2020). Resource Sharing: Vehicle for Effective Library Information Dissemination and Services in the Digital Age (pages 70-92), In A. Tella (Eds), Digital Devices for Inclusivity and Engagement in Libraries, IGI Global Publishers, USA. DOI: 10.4018/978-1-5225-9034-7.ch004.

49. Wise, S., Henninger, M., \& Kennan, M.A. (2011). Changing trends in LIS job advertisements. Australian Academic and Research Libraries, 42(4), 268-295. 
50. Womboh, B.S.H. and Abba, T. (2008). The state of information and communication technology (ICT) in Nigerian University Libraries: the experience of Ibrahim Babangida Library, Federal University of Technology, Yola", Library Philosophy and Practice.

51. University of Queensland Australia (2020). Artificial intelligence. Retrieved from https://web.library.uq.edu.au/research-tools-techniques/digital-essentials/artificialintelligence 